\title{
Bone marrow $T$ cells from the femur are similar to iliac crest derived cells in old age and represent a useful tool for studying the aged immune system
}

Theresa Pritz ${ }^{1}$, Katja Landgraf-Rauf ${ }^{1}$, Dietmar Herndler-Brandstetter ${ }^{1,4}$, Rauend Rauf ${ }^{2}$, Julian Lair ${ }^{2}$, Robert Gassner ${ }^{3}$, Birgit Weinberger ${ }^{1}$, Martin Krismer ${ }^{2}$ and Beatrix Grubeck-Loebenstein ${ }^{1 *}$

\begin{abstract}
Background: $\mathrm{CD}^{+}$and $\mathrm{CD} 8^{+} \mathrm{T}$ cells reside in the human bone marrow (BM) and show a heightened activation state. However, only small sample sizes are available from sources such as the iliac crest. Larger samples can be obtained from the femur in the course of hip replacement surgery. It was therefore the goal of the present study to compare the phenotype and function of BM T cells from different sources from elderly persons and to investigate how femur derived bone marrow $T$ cells can serve as a tool to gain a better understanding of the role of adaptive immune cells in the BM in old age.

Results: Bone marrow mononuclear cells (BMMC) were isolated from either the iliac crest or the femur shaft. As expected the yield of mononuclear cells was higher from femur than from iliac crest samples. There were no phenotypic differences between BMMC from the two sources. Compared to PBMC, both BM sample types contained fewer naïve and more antigen experienced $C D 4^{+}$as well as $C D 8^{+} \mathrm{T}$ cells, which, in contrast to peripheral cells, expressed CD69. Cytokine production was also similar in T cells from both BM types. Larger sample sizes allowed the generation of $T$ cell lines from femur derived bone marrow using non-specific as well as specific stimulation. The phenotype of T cell lines generated by stimulation with OKT-3 and IL-2 for two weeks was very similar to the one of ex vivo BM derived T cells. Such lines can be used for studies on the interaction of different types of BM cells as shown by co-culture experiments with BM derived stromal cells. Using CMV NLV Specific T cell lines we additionally demonstrated that BM samples from the femur are suitable for the generation of antigen specific T cell lines, which can be used in studies on the clonal composition of antigen specific BM T cells.
\end{abstract}

Conclusion: In conclusion, our results demonstrate that BMMC from the femur shaft are a useful tool for studies on the role of T cells in the BM in old age.

Keywords: Bone marrow, lliac crest, Femur, Peripheral blood, Mononuclear cells, T cells, Cytokines, T cell lines, Cytomegalovirus

\section{Background}

Recent studies indicate that the bone marrow (BM) is a lymphoid organ which is important for adaptive immune responses [1]. In mice it has been shown that a major proportion of memory $\mathrm{CD} 4^{+}$and $\mathrm{CD} 8^{+} \mathrm{T}$ cells is located in the $\mathrm{BM}$ and remains there for a prolonged period of

\footnotetext{
*Correspondence: beatrix.grubeck@uibk.ac.at

'Institute for Biomedical Aging Research, University Innsbruck, Rennweg 10, Innsbruck, Austria

Full list of author information is available at the end of the article
}

time in distinct survival niches [2]. The situation seems to be similar in humans [3].

Yet, little information is available on the role of the human BM in adaptive immune responses during aging. Our group has contributed to this topic using BM from iliac crest from young and elderly persons. Our results show that the number of $\mathrm{CD}_{4}^{+}$and $\mathrm{CD} 8^{+} \mathrm{T}$ cells in the $\mathrm{BM}$ is maintained during aging and that these cells are in a heightened activation state. However, the composition of the T cell pool in the aged BM is altered with a

\section{Biomed Central}

(c) 2013 Pritz et al.; licensee BioMed Central Ltd. This is an Open Access article distributed under the terms of the Creative Commons Attribution License (http://creativecommons.org/licenses/by/2.0), which permits unrestricted use, distribution, and reproduction in any medium, provided the original work is properly cited. 
decline of naïve and an increase in effector memory $\mathrm{T}$ cells [4].

In previous studies we used iliac crest samples from patients undergoing reconstructive surgery and bone remodeling of the jaw following accidents or for dental implants. The major advantage of this source of bone marrow is that it is obtained from healthy donors of different age groups. However, the samples are generally very small with a low yield of BMMC. For many research questions higher cell numbers are needed. BM samples obtained from healthy donors by aspiration, e.g. for bone marrow transplantation frequently contain large numbers of peripheral mononuclear cells [5], which makes them unsuitable for studies in which e.g. $\mathrm{T}$ cell composition in the bone marrow is analyzed in direct comparison to peripheral blood. We therefore tested a different source of BM, namely the femur shaft. BM from the femur shaft is available from patients undergoing total hip replacement [6]. Following collagenase digestions it is possible to isolate relatively high numbers of BMMC from these samples. A potential problem may be the close vicinity of the femur shaft to the inflamed joint in patients who undergo hip replacement, or the fact that these patients are frequently treated with antiinflammatory drugs. In order to be suitable for studies on the physiology of the aging immune system the possibility that inflammatory processes and/or drugs could influence the composition and activation state of adaptive immune cells needs to be excluded. It was therefore the goal of our present study to compare the phenotype and function of BM T cells from the iliac crest and the femur shaft. We show that inflammatory processes in the joint do not affect the phenotype and function of $\mathrm{T}$ cells in the BM obtained from femur samples. We also suggest approaches how BMMC from the femur can be used for studies on the role of BM T cells in old age.

\section{Results}

Comparison of $\mathrm{CD}^{+}$and $\mathrm{CD} 8^{+} \mathrm{T}$ cell phenotypes within BM from different sources

We first compared the composition of the $\mathrm{CD}^{+}$and $\mathrm{CD}^{+} \mathrm{T}$ cell pool in BM obtained from either the femur or iliac crest from elderly persons. Expectedly, the yield of BMMC was higher from femur than from iliac crest samples $\left(21.6 \times 10^{6} \pm 2.5 ; \mathrm{n}=13\right.$ : femur versus $4.77 \times 10^{6} \pm 1.3$; $\mathrm{n}=13$ : iliac crest; $\mathrm{p}<0.001)$. We analyzed the expression of the surface molecules CD45RA and CCR7 to define naïve $\left(C D 45 R A^{+} C C R 7^{+}\right)$, central memory $\left(C D 45 R A^{-}\right.$ $\mathrm{CCR7}^{+}$), effector memory (CD45RA ${ }^{-} \mathrm{CCR}^{-}$) and $\mathrm{T}_{\text {EMRA }}$ cells $\left(\mathrm{CD}^{2} 5 \mathrm{RA}^{+} \mathrm{CCR}^{-}\right)$. The relative numbers of $\mathrm{CD}^{+}$as well as $\mathrm{CD}^{+} \mathrm{T}$ cell subsets were similar in samples obtained from the femur and the iliac crest (Table 1). We were able to confirm characteristic differences between $\mathrm{BMMC}$ and PBMC, which were previously described by
Table 1 Comparison of mononuclear cells from different sources of BM and from peripheral blood (PB)

\begin{tabular}{|c|c|c|c|c|}
\hline \multirow[b]{2}{*}{$\mathrm{CD}^{+}$} & \multicolumn{3}{|c|}{ BM } & \multirow{2}{*}{$\begin{array}{c}\text { PB } \\
(n=16)\end{array}$} \\
\hline & $\begin{array}{l}\text { Femur } \\
(n=8)\end{array}$ & $\begin{array}{l}\text { Iliac crest } \\
(n=8)\end{array}$ & $\mathbf{P}^{\#}$ & \\
\hline$\% \mathrm{CCR7}^{+} \mathrm{CD} 45 \mathrm{RA}^{+}\left(\mathrm{T}_{\mathrm{N}}\right)$ & $26.1 \pm 2.3$ & $19.8 \pm 1.9$ & 0.08 & $34.8 \pm 2.9^{* / \S}$ \\
\hline$\% C C R 7^{+}{ }^{-C D 45 R A^{-}}\left(T_{C M}\right)$ & $21.9 \pm 5.9$ & $24.4 \pm 3.1$ & 0.89 & $28.8 \pm 3.7$ \\
\hline$\%$ CCR7 CD45RA $^{-}\left(T_{E M}\right)$ & $34.6 \pm 4.4$ & $44.3 \pm 3.6$ & 0.11 & $23.8 \pm 3.3^{* / \S}$ \\
\hline$\% C^{2} 7^{-C D} 45 R^{+}\left(T_{\text {EMRA }}\right)$ & $12.1 \pm 3.3$ & $13.4 \pm 3.0$ & 0.80 & $15.7 \pm 2.7$ \\
\hline CD69 & $16.9 \pm 3.1$ & $15.9 \pm 2.3$ & 0.69 & $0.7 \pm 0.1^{* / \S}$ \\
\hline $\mathrm{CD}^{+}$ & $\begin{array}{l}\text { Femur } \\
(n=8)\end{array}$ & $\begin{array}{l}\text { Iliac crest } \\
(n=8)\end{array}$ & & $(n=16)$ \\
\hline$\% \mathrm{CCR7}^{+} \mathrm{CD} 45 \mathrm{RA}^{+}\left(\mathrm{T}_{\mathrm{N}}\right)$ & $17.8 \pm 3.5$ & $14.1 \pm 3.2$ & 0.47 & $29.3 \pm 3.4^{* / \S}$ \\
\hline$\% C C R 7^{+}$CD45RA $^{-}\left(T_{C M}\right)$ & $16.7 \pm 3.1$ & $10.9 \pm 4.1$ & 0.68 & $14.5 \pm 2.2$ \\
\hline$\%$ CCR7'CD45RA- $^{-}\left(T_{E M}\right)$ & $29.1 \pm 4.2$ & $34.1 \pm 6.7$ & 0.64 & $21.9 \pm 2.6^{* / \S}$ \\
\hline$\% \mathrm{CCR7}^{-} \mathrm{CD}^{2} 5 \mathrm{RA}^{+}\left(\mathrm{T}_{\text {EMRA }}\right)$ & $33.0 \pm 0.5$ & $41.6 \pm 5.9$ & 0.59 & $39.5 \pm 3.7$ \\
\hline CD69 & $39.0 \pm 6.1$ & $46.3 \pm 4.1$ & 0.59 & $1.9 \pm 0.4^{* / \S}$ \\
\hline
\end{tabular}

BM was obtained either from the femur shaft or from iliac crest, as described in Materials and Methods. All samples were from elderly persons (mean age \pm SEM: femur $68.6 \pm 2.1$ years; iliac crest $66 \pm 3.1$ years). Data were calculated using $t$ test and are presented as mean \pm SEM. ${ }^{*} \mathrm{p}<0.05$ : PBMC vs. femur derived BMMC; ${ }^{5} \mathrm{p}<0.05$ : PBMC vs. iliac crest-derived BMMC. There were no significant differences between samples obtained from the two different sources of $B M . ~ " P$ values: femur versus iliac crest.

our group [3,4]. While the numbers of naïve $\mathrm{CD} 4^{+} \mathrm{T}$ as well as $\mathrm{CD} 8^{+} \mathrm{T}$ cells were decreased in both types of $\mathrm{BM}$ compared to $\mathrm{PB}$, there was an increase in the numbers of effector memory $\mathrm{T}$ cells in the BM. In accordance with our previous results, a relatively large percentage of BM T cells expressed CD69. Again there were no differences in the number of $\mathrm{CD} 9^{+}$cells in $\mathrm{BM}$ samples from femur and iliac crest. In addition to the data in Table 1, we plotted the data on $\mathrm{T}$ cell subsets versus age as a continuous variable for femur $\mathrm{BM}$ and $\mathrm{PB}$, and linked $\mathrm{BMMC}$ and PBMC values in each donor (Figure 1). Characteristic age related changes in the relative numbers of $T_{N}$ and $T_{E M}$ can be seen. The impact of CMV infection on the distribution of $\mathrm{T}$ cell subsets in the BM from iliac crest as well as from femur is similar to what is known from the periphery ([4] and data not shown).

\section{BMMC obtained from the femur and iliac crest have a similar cytokine production pattern}

Intracellular cytokine staining was performed in order to assess possible differences in cytokine production in BMMC isolated from the femur or the iliac crest. In a first set of experiments the occurrence of polyfunctional $\mathrm{T}$ cells was analyzed within the total $\mathrm{CD} 4^{+}$and $\mathrm{CD} 8^{+} \mathrm{T}$ cell populations. The occurrence of polyfunctional $\mathrm{T}$ cells was similar in cells derived from either the femur or the iliac crest. In accordance with our previous results [3,4], the number of cells secreting three cytokines was higher in $\mathrm{T}$ 


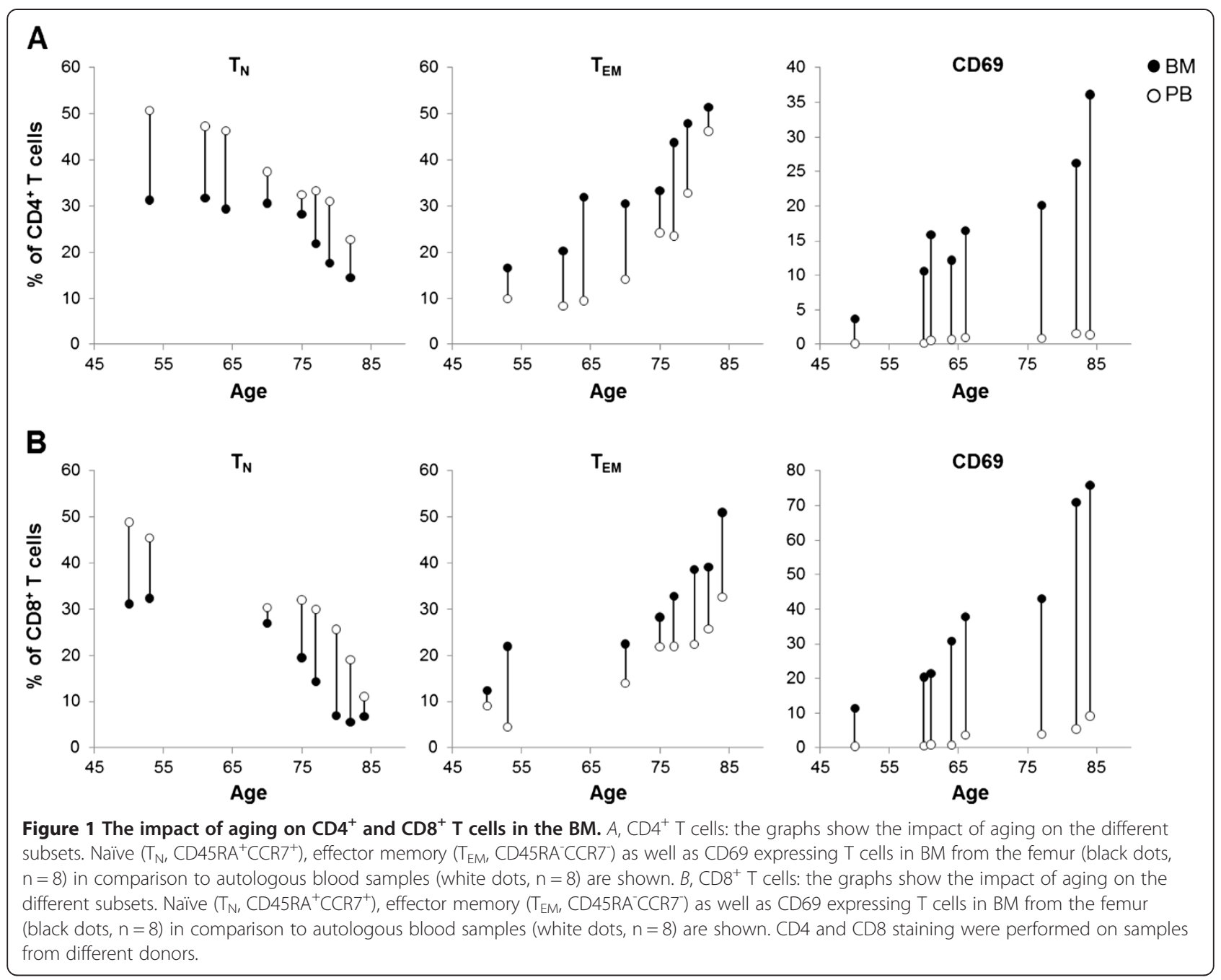

cells from the BM than from the PB $(\mathrm{p}<0.05)$. Data on total $\mathrm{CD}^{+} \mathrm{T}$ cells are depicted in Figure 2A. Similar results were obtained for $\mathrm{CD} 4^{+} \mathrm{T}$ cells (data not shown). As higher numbers of BMMC were available from the femur than from the iliac crest, a more detailed analysis of cytokine production was possible using femur derived cells. The cytokine production profile of naïve, central memory, effector memory and $\mathrm{T}_{\mathrm{EMRA}}$ cells isolated from femur derived BM was compared to the cytokine production in corresponding subsets from the PB. Cytokine production by $\mathrm{CD}^{+} \mathrm{T}$ cell subsets is shown in Figure $2 \mathrm{~B}$. Following stimulation, the majority of naïve $\mathrm{T}$ cells from both sources produced only one cytokine, mostly IL-2 or TNF $\alpha$. The remaining cells produced either a combination of IL- 2 and TNF $\alpha$ or of IFN $\gamma$ and TNF $\alpha$, while the fraction of triple positive cells was relatively small in both types of naïve samples. In contrast, the percentage of cells producing only one cytokine was significantly lower in antigen experienced cells derived from the BM than in corresponding populations from the $\mathrm{PB}(\mathrm{p}<0.05)$. In accordance with this, the percentage of double/triple positive cells was higher in antigen experienced cells from the BM than in the corresponding subpopulations from the $\mathrm{PB}(\mathrm{p}<0.05)$. Expectedly, the percentage of IL-2 producing cells decreased with $T$ cell differentiation, while the percentage of IFN $\gamma / \mathrm{TNF} \alpha$ producing cells was highest in the $\mathrm{T}_{\text {EMRA }}$ subsets and even further increased in the $\mathrm{T}_{\mathrm{EMRA}}$ population from the BM compared to the $\mathrm{PB}(\mathrm{p}<0.05)$. Similar results were obtained for $\mathrm{CD}^{+} \mathrm{T}$ cells (data not shown). Our results demonstrate that $\mathrm{T}$ cells from the $\mathrm{BM}$ are functionally more active than corresponding cells from the $\mathrm{PB}$ and that $\mathrm{BM}$ derived $\mathrm{T}$ cells of a high differentiation stage can produce a variety of different cytokines.

\section{Generation of T cell lines from BM samples by non-specific stimulation}

For many functional tests, in particular studies on the interaction of $\mathrm{T}$ cells with other cell types such as stromal cells, the number of ex vivo obtainable $\mathrm{T}$ cells is not 
A
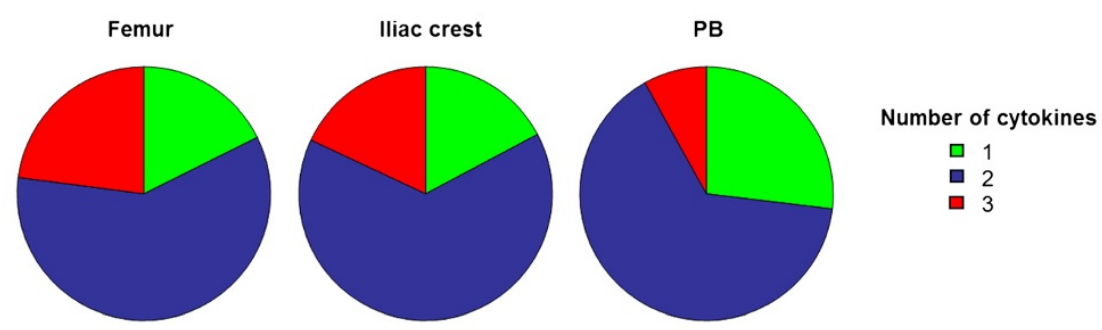

B

BM
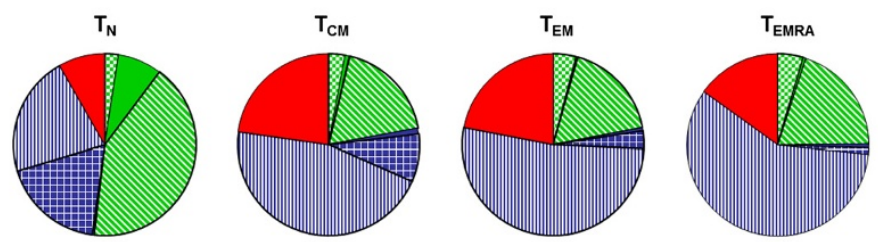

曰IFNY

$\square$ IL-2

$\triangle \mathrm{TNFa}$

- IFNY/IL-2

IL-2/TNFa

m IFNYTNFa

I IFNY/LL-2/TNFa
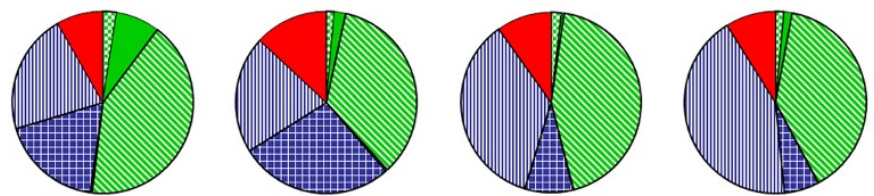

Figure 2 Cytokine production by $\mathrm{CD}^{+} \mathbf{T}$ cell in the BM and the PB. BMMC from the femur $(n=14)$ or iliac crest $(n=5)$ and PBMC $(n=19)$ from healthy elderly persons were stimulated with PMA and ionomycin in the presence of brefeldin $\mathrm{A}$ for $4 \mathrm{~h}$ and the production of the cytokines IFN- $\gamma$, TNF- $a$ and IL-2 was determined by intracellular FACS analysis. A, CD8 ${ }^{+}$T cells producing cytokines after stimulation are depicted and the pie charts show the percentages of $C D 8^{+} T$ cells producing one (green), two (blue) or three cytokines (red). B, Cytokine production of $C D 8^{+}$naive $\left(T_{N}\right)$, central memory $\left(T_{C M}\right)$, effector memory $\left(T_{E M}\right)$, and $T_{E M R A}$ was analyzed in femur derived BMMC $(n=12)$ and PBMC $(n=12)$ from the same donors. The pie chart represents percentages of T cells expressing different combinations of cytokines as indicated.

high enough, even when BM samples from the femur are used. We therefore expanded BM derived $\mathrm{T}$ cells from femur samples from two donors by stimulation with an anti-CD3 antibody and IL-2. After two weeks of culture we were able to increase the number of $\mathrm{T}$ cells by approximately 20 -fold. We then analyzed the phenotype of the obtained lines in comparison to the original ex vivo populations. In accordance with our previous findings the $\mathrm{BM}$ samples contained more $\mathrm{CD}^{+}$than $\mathrm{CD} 4^{+} \mathrm{T}$ cells, which is in contrast to the situation in peripheral blood $[3,4]$. After two weeks in culture the ratio of $\mathrm{CD}^{+} / \mathrm{CD}^{+} \mathrm{T}$ cells was further decreased. However, the percentage of $\mathrm{CD}_{2} 8^{-} \mathrm{T}$ cells was relatively constant during the cultivation period and corresponded to the population obtained ex vivo (data not shown). Nonspecifically expanded $\mathrm{T}$ cell lines are therefore a suitable model to study the function of BM derived T cells.

\section{Effect of BM derived stromal cells on bone marrow derived $\mathrm{T}$ cell lines}

In addition to lymphocytes, stromal cells can be isolated from human BM. These stromal cells contain mesenchymal stem cells, which can be isolated and cultivated in vitro [7] and have suppressive effects on $\mathrm{T}$ cell function [8]. However, the effect of other stromal cell types on $\mathrm{T}$ cell function is less well studied and we therefore tested the suitability of $\mathrm{BM}$ derived $\mathrm{T}$ cell lines for studies on the interaction of $\mathrm{T}$ cells and stromal cells. $\mathrm{BM}$ derived $\mathrm{T}$ cell lines were stimulated with either IL15 (homeostatic stimulation) or a combination of antiCD3 antibody and IL-2 (antigenic stimulation) in the absence or presence of autologous stromal cells. The presence of stromal cells had no influence on the $\mathrm{T}$ cell phenotype (data not shown). Our results additionally showed that BM stromal cells did not have a suppressive effect on the proliferation of $\mathrm{BM}$ derived $\mathrm{T}$ cell lines in response to stimulation (Figure 3).

The clonal composition of the $\mathrm{CD}^{+} \mathrm{T}$ cell pool in the $\mathrm{BM}$ in comparison to the PB: The example of CMV specific cells

To analyze the clonal composition of BM derived $\mathrm{T}$ cells of a certain specificity, we stimulated BMMC as well as PBMC with the peptide $\mathrm{CMV}_{\mathrm{NLV}}$ for two weeks following a previously published protocol $[9,10]$. It was of interest that the starting population from the BM contained more $\mathrm{CMV}_{\mathrm{NLV}}$ specific cells than the corresponding population from the PB $(12.5 \% \pm 3.2, \mathrm{n}=5$ : $\mathrm{BM}$ versus $5.0 \% \pm 3.6$; $\mathrm{n}=5: \mathrm{PB} ; \mathrm{p}<0.01)$. A representative staining is shown in Figure 4A. BMMC and PBMC from three donors were used for the establishment of antigen specific $\mathrm{T}$ cell lines. After 14 days of culture $\mathrm{CMV}_{\mathrm{NLV}}$ specific $\mathrm{T}$ cells were purified using allophycocyanin (APC)-conjugated $\mathrm{CMV}_{\mathrm{NLV}}$ pentamers, anti-APC-antibodies coupled with magnetic beads and MACS technology. The purity of the 


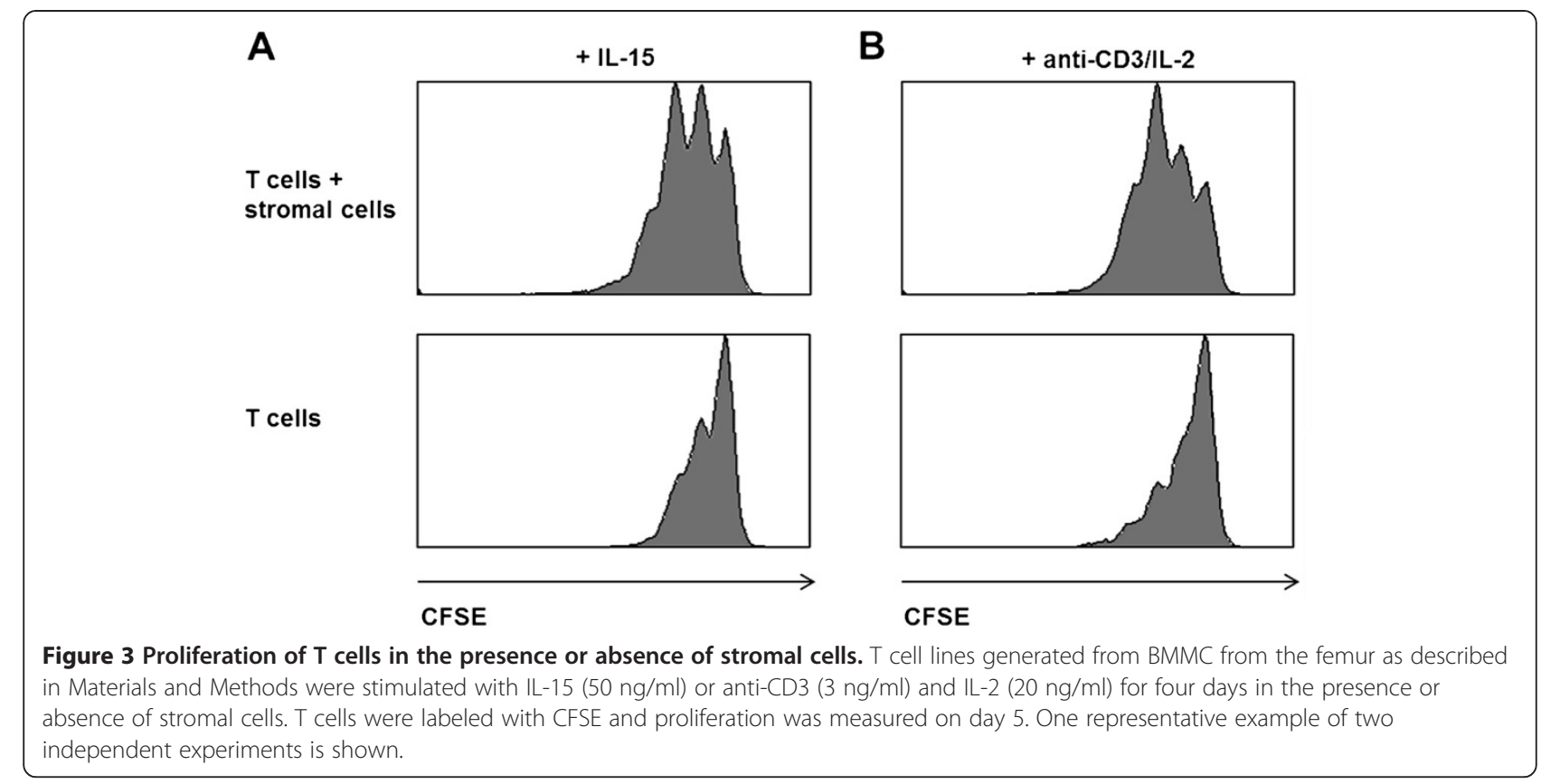

$6 \mathrm{~T}$ cell lines was above 95\% after purification (Figure 4A). RNA was isolated from the T cell lines and cDNA synthesis was performed using a reverse transcription system, as described in Materials and Methods. TCR fragments were amplified from cDNA for $24 \mathrm{~V} \beta$ families (BV) and complementarity determining region (CDR3) spectratyping was performed. While some cDNA clones, in particular within the $V \beta 8$ and $V \beta 13$ family, were identical in the $T$ cell lines derived from the $\mathrm{BM}$ and the $\mathrm{PB}$ (Figure $4 \mathrm{~B}$, upper panel), other cDNA clones occurred exclusively in the $\mathrm{BM}$ or in the PB (Figure 4B, lower panel). This fact is further underlined by the results depicted in Figure 4C, in which the spectratyping data of the $6 \mathrm{CMV}_{\mathrm{NLV}}$ specific $\mathrm{T}$ cell lines obtained from three individual donors are summarized. The $\mathrm{CMV}_{\mathrm{NLV}}$ specific $\mathrm{T}$ cell lines generated from donor 1 were both relatively polyclonal, which was most likely due to the fact that this donor was younger than the other two donors from whom we obtained material (donors 2 and 3). There were still $5 \mathrm{~V} \beta$ families $(1,4,5.3$, 15 and 16), in which cDNA clones were only found in the $\mathrm{BM}$ derived, but not in the peripheral $\mathrm{T}$ cell line. On the other hand, $4 \mathrm{~V} \beta$ families (5.1, 11, 20 and 23) only contained cDNA clones in the peripheral, but not the BM derived $\mathrm{CMV}_{\mathrm{NLV}}$ specific $\mathrm{T}$ cell line. In comparison, the $\mathrm{T}$ cell lines generated from donors 2 and 3 had a more restricted diversity and this restriction seemed to be even more pronounced in $\mathrm{BM}$ derived $\mathrm{CMV}_{\mathrm{NLV}}$ specific $\mathrm{T}$ cell lines. Thus, V $\beta 20$ positive cDNA clones were only detected in the BM derived T cell line, but not in the peripheral line, $\mathrm{V} \beta$ 5.1, 5.3, 7, 9 and 14 cDNA clones were only found in the peripheral T cell line, but not in the BM derived one from donor 2 . The picture was similar in the
$\mathrm{CMV}_{\mathrm{NLV}}$ specific $\mathrm{T}$ cell lines derived from donor 3: Two $\mathrm{V} \beta$ families $(5.1,12)$ contained $\mathrm{CMV}_{\mathrm{NLV}}$ specific cDNA clones in the BM derived line only, while $7 \mathrm{~V} \beta$ families $(1,4,6.1,6.2,7,20,21)$ contained cDNA clones in the peripheral, but not in the BM derived T cell line.

\section{Discussion}

In the present study we used femur as well as iliac crest to isolate BMMC from the BM of elderly persons and compared the phenotype and function of $\mathrm{T}$ cells within these two preparations. In the past we used iliac crest samples from patients undergoing reconstructive surgery and bone remodeling of the jaw following accidents or for dental implants. These persons are known to be healthy and are not treated with any immunemodulatory drugs. In contrast, femur BM is obtained from patients undergoing hip replacement surgery. They suffer from inflammation of the joint and are frequently treated with anti-inflammatory drugs. Both factors might affect the composition of the $\mathrm{T}$ cell pool as well as the activation state of BM derived $\mathrm{T}$ cells from the femur shaft region, which could compromise the suitability of this material for functional analyses of BM derived T cells. We clearly demonstrate that this is not the case, as the size of the different $T$ cell subsets, their activation state, and their cytokine production profile was not different between samples obtained from the two tissue sources. We can therefore conclude that BM from the femur shaft can be considered as healthy and suitable for physiological studies.

As the yield of BMMC from the femur is significantly larger than from the iliac crest, femur BMMC can be used for more sophisticated experimental approaches 


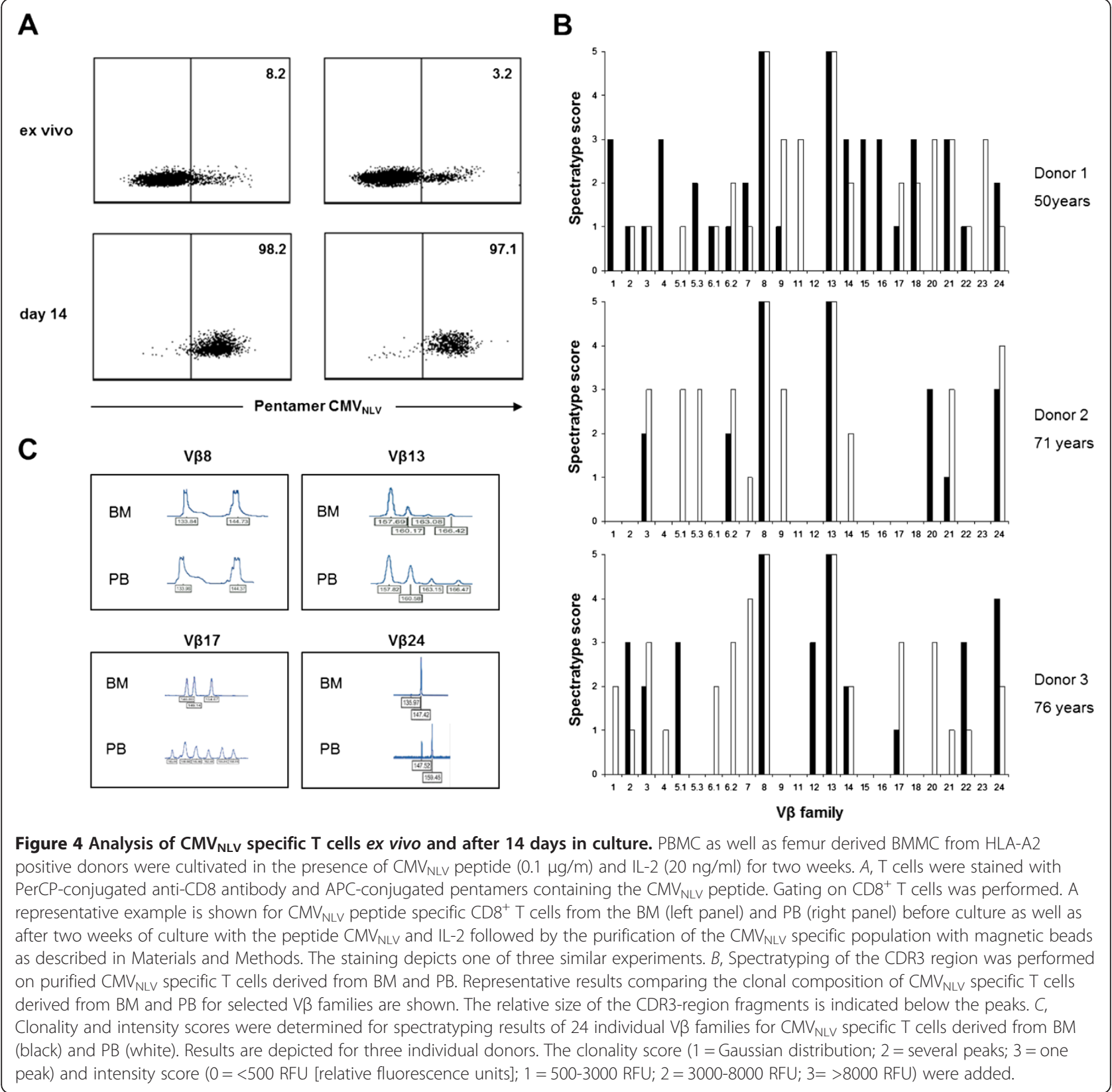

leading to more detailed results. In samples from the iliac crest it was only possible to define the cytokine production of the total $\mathrm{CD}^{+}$and $\mathrm{CD} 4^{+} \mathrm{T}$ cell populations. However, using femur derived BMMC we were able to analyze the production of several cytokines separately in $\mathrm{T}$ cell subsets, namely naïve, central memory, effector memory and $\mathrm{T}_{\mathrm{EMRA}}$ cells. These data were of interest, as $\mathrm{T}$ cells of late differentiation stages were more frequently polyfunctional in the $\mathrm{BM}$ than in the $\mathrm{PB}$. These data support our concept that $\mathrm{CCR}^{-}$cells, which are otherwise susceptible to apoptosis-inducing stimuli and destined to perish [11], may not only survive, but also function in the
IL-15 rich BM microenvironment in old age [3,4]. Whether these highly differentiated $\mathrm{T}$ cells in the BM of elderly people represent a useful line of defense in the absence of fully functioning naïve T cells $[12,13]$ or take up space otherwise reserved for $\mathrm{CD} 4^{+} \mathrm{T}$ cells of an earlier differentiation stage or for long-lived plasma cells $[14,15]$ is not yet known. Further studies will be needed to clarify this open question.

One possible approach to address these issues is the in vitro modeling of the in vivo situation by co-culturing $\mathrm{BM}$ derived $\mathrm{T}$ cells and $\mathrm{BM}$ derived stromal cells. As in humans both cell types are not available in sufficiently 
high numbers for functional analysis in ex vivo samples, even in the relatively large BM samples from the femur, the generation of cell lines is a prerequisite to allow conclusive experimental setups. Our results show that $\mathrm{T}$ cell lines generated from BMMC by non-specific stimulation maintain the characteristic phenotype of the original population. They also demonstrate that proliferation of the lines in response to stimulation with both, anti-CD3 antibody or IL-15, is not negatively affected by the presence of stromal cells. This may be surprising, as there are multiple reports in the literature that BM derived mesenchymal stem cells have immunsuppressive effects on $\mathrm{T}$ cells [16]. Because of their immunomodulatory properties mesenchymal stromal cells are already being used in clinical trials for preventing graft vs. host disease and other disorders going along with increased immune responsiveness $[17,18]$. In view of our results it seems likely that only stromal cells of early differentiation stages, which may still be multipotent, are capable of immunosuppressive effects. Our in vitro model system will represent a useful tool to analyze how stromal cells of different phenotypes - from early differentiation stages to senescence - affect the function of different $\mathrm{T}$ cell subsets.

In this context it will also be important to analyze how stromal cells affect $\mathrm{T}$ cell responses to different antigens. Our data clearly indicate that the clonal composition of a $\mathrm{CMV}_{\mathrm{NLV}}$ specific $\mathrm{T}$ cell population is different in the $\mathrm{BM}$ and in the periphery. With the exception of $\mathrm{V} \beta 8^{+}$and $\mathrm{V} \beta$ $13^{+} \mathrm{T}$ cells, which are known to dominate $\mathrm{CMV}_{\mathrm{NLV}}$ specific responses $[9,19]$, a relatively large number of clones is found in the $\mathrm{BM}$, but not in the $\mathrm{PB}$ and vice versa. Our data also suggest that the $\mathrm{CMV}_{\mathrm{NLV}}$ specific $\mathrm{T}$ cell repertoire in the $\mathrm{BM}$ is more restricted than in the periphery. It will be a challenge to identify BM specific clones, isolate them and analyze their avidity and function. A similar approach using peripheral $\mathrm{T}$ cells has in the past been successfully used by our group and others [20,21]. As CMV is believed to accelerate the aging of the immune system [22-24], it will be of special interest to define the exact role of CMV specific clones which reside in the $\mathrm{BM}$ in the infection / reactivation process.

\section{Conclusion}

In conclusion, our results demonstrate that the BMMC population derived from the femur shaft provides a useful tool for a variety of immunological studies addressing questions of major importance. New insights thus obtained will improve our understanding of age-related changes of immune function in old age.

\section{Materials and methods}

\section{Sample collection and preparation}

Paired blood and BM samples were obtained from systemically healthy elderly persons. Individuals who suffered from diseases known to influence the immune system, including autoimmune diseases and cancer, were excluded from the study. Femur derived BM and autologous blood samples were obtained from a total of 32 donors (19 females, 13 males, mean age \pm SEM: $68.6 \pm$ 2.1 years). CMV specific antibodies were measured in serum. 24 donors were sero-positive and 8 donors were sero-negative for CMV. Iliac crest material and blood were obtained from a total of 30 donors ( 22 females, 8 males, mean age \pm SEM: $66 \pm 3.1$ years). The CMV serostatus was only known from seven patients, 4 donors were CMV sero-positive and 3 donors were CMV sero-negative. Informed written consent was obtained and the study was approved by the Ethics Committee of Innsbruck Medical University. Bone from the femur shaft was harvested at the Department of Orthopedic Surgery at Innsbruck Medical University from patients undergoing hip replacement surgery. A biopsy of substantia spongiosa ossium, which would otherwise have been discarded, was used to isolate BMMC. BMMC samples from the iliac crest of elderly persons were obtained as previously described [3,4]. In brief, bone from the iliac crest was harvested at the Department of Cranio-Maxillofacial and Oral Surgery at Innsbruck Medical University for bone molding/recontouring prior to insertion into other areas of the body, in particular facial regions. A biopsy of substantia spongiosa ossium, which would otherwise have been discarded, was used to isolate BMMC. Results on some of the iliac crest derived samples used in this study have been described in a different context $[3,4]$. Both types of bone biopsies were washed once with complete RPMI 1640 (Lonza) supplemented with 10\% FCS (Sigma Aldrich), 1\% Penicillin/Streptomycin (PAA). Bone biopsies were then fragmented and treated with sterile-filtered, chromatographically purified collagenase (CLSPA; Worthington; $20 \mathrm{U} / \mathrm{ml}$ in complete RPMI) for $2 \mathrm{~h}$ at $37^{\circ} \mathrm{C}, 20 \%$ $\mathrm{O}_{2}$ and $5 \% \mathrm{CO}_{2}$. Cells were centrifuged, and BMMC were purified by density-gradient centrifugation (FicollHypaque). Preparation of PBMC was also performed by density-gradient centrifugation.

\section{Flow cytometric analysis}

Immunofluorescence surface staining was performed by adding a panel of directly conjugated mAb to freshly prepared $\mathrm{PBMC}, \mathrm{BMMC}$ or $\mathrm{T}$ cell lines, respectively. The Abs used were: $\mathrm{CD} 3$ (PE-Cy7 and APC-Cy7), CD4 (FITC, PerCP and PE-Cy7), CD28 (APC), CD45RA (PE, PerCP and APC) CD69 (FITC and PE) (all BD Pharmingen), CD8 (PerCP; Biolegend) and CCR7 (FITC; $R \& D$ Systems). Cells were incubated with the antibodies for $30 \mathrm{~min}$ at $4^{\circ} \mathrm{C}$. The labeled cells were measured by a FACSCanto II Instrument (BD Biosciences), and the data were analyzed using FACSDiva software (BD Biosciences). 


\section{Intracellular cytokine staining}

The production of cytokines by $\mathrm{T}$ cells from the BM and PB was assessed by stimulating the cells for $4 \mathrm{~h}$ with $30 \mathrm{ng} / \mathrm{ml}$ PMA and $500 \mathrm{ng} / \mathrm{ml}$ ionomycin in the presence of $10 \mu \mathrm{g} / \mathrm{ml}$ brefeldin A (all Sigma-Aldrich). Cells were permeabilized using the Cytofix/Cytoperm kit (BD Pharmingen) and intracellular staining of IFN $-\gamma$ (FITC), TNF- $\alpha$ (PE) and IL-2 (PE-Cy7) (all BD Pharmingen) was performed following manufacturer's instructions. In intracellular cytokine staining experiments naïve cells were defined as CD45RA ${ }^{+} \mathrm{CD} 28^{+}$, central memory cells as CD45RA ${ }^{-} \mathrm{CD}^{+} 8^{+}$, effector memory cells as CD45RA ${ }^{-}$ CD28 $8^{-}$and $\mathrm{T}_{\text {EMRA }}$ as CD45RA ${ }^{+} \mathrm{CD}^{-} 8^{-}$.

\section{Pentamer staining}

For the detection of CMV pp65 NLVPMVATV (CMV $\mathrm{NLV})$ peptide specific $\mathrm{CD}^{+} \mathrm{T}$ cells in HLA-A2 positive, CMV positive persons, the cells were stained with $\mathrm{CMV}_{\mathrm{NLV}}$ Pro5 ${ }^{\circledR}$ MHC Pentamer (Proimmune) and incubated for $10 \mathrm{~min}$ at RT in the dark before staining for other surface markers was performed.

\section{Cell culture}

Cell culture experiments were performed with RPMI 1640 (Lonza) supplemented with 10\% FCS (Sigma-Aldrich) and 1\% Penicillin/Streptomycin (PAA).

For non-specific expansion, femur derived BMMC and PBMC from two HLA-A2 positive donors were stimulated with anti-CD3 (3 ng/ml) (BD Pharmingen) and IL-2 (20 ng/ml) (Novartis) for 2 weeks. During this time they were restimulated once a week with anti-CD3 antibody and every third day with IL-2.

To generate $\mathrm{CMV}_{\mathrm{NLV}}$ peptide-specific $\mathrm{CD}^{+} \mathrm{T}$ cell populations, femur derived BMMC and PBMC from three HLA-A2 positive, CMV positive elderly donors were incubated with $0.1 \mu \mathrm{g} / \mathrm{ml}$ pp65 $\mathrm{CMV}_{\mathrm{NLV}}$ peptide (NLVPMVATV; Bachem) for two weeks. During this time they were restimulated with IL-2 (20 ng/ml) (Novartis) every three days and with peptide once on day 7. After 14 days $\mathrm{CMV}_{\mathrm{NLV}}$ specific $\mathrm{CD} 8^{+}$T cells were purified using MACS technology, as previously described [10]. Briefly, CMV specific $\mathrm{CD}^{+} \mathrm{T}$ cells were positively selected using APC-coupled $C M V_{N L V}$ pentamers, followed by the addition of anti-APC-antibodies coupled with magnetic beads (all (BD Pharmingen) and a LS column (Miltenyi Biotec). The purity of the $\mathrm{CMV}_{\mathrm{NLV}}$ specific $\mathrm{CD}^{+} \mathrm{T}$ cell lines was $>95 \%$ after purification.

\section{TCR V $\beta$ CDR3 spectratyping analysis}

TCR V $\beta$ transcripts of $C M V_{N L V}$ specific $T$ cells from the femur derived BM and PB were amplified by PCR using HotStarTaq Master Mix Kit (Qiagen), primers (MWG Biotech) specific for each of the 24 human $V \beta$ families and a specific primer for the $C$ region of the $\beta$-chain (labeled with the fluorescent dye marker 6-FAM) as previously described $[19,25]$. An aliquot of the PCR product was diluted in $20 \mu \mathrm{l}$ deionized formamide and $1.2 \mathrm{fmol}$ internal lane standard GeneScan-350 Tamra (PerkinElmer). The samples were denatured at $90^{\circ} \mathrm{C}$ for 2 min and loaded on a CE 3100 Genetic Analyzer (PerkinElmer). Each sample was injected for $5 \mathrm{~s}$ at $15 \mathrm{kV}$ and electrophoresed for $24 \mathrm{~min}$ at $10 \mathrm{kV}$ using a $36-\mathrm{cm}$ capillary and POP46 (PerkinElmer). Analysis of the raw data was performed applying the GeneScan 3.7 analysis software package (Applies Biosyststems) using the Local Southern method for fragment size estimation. For each $V \beta$ family the occurrence of dominant clonal expansions was quantified by assigning scores for clonality and intensity as previously described [9]. The clonality score $(1=$ Gaussian distributed; 2 = several peaks; 3 = one peak) and intensity score $(0=<500 \mathrm{RFU}$ [relative fluorescence units]; $1=500-3000$ RFU; 2 = 3000-8000 RFU; $3=>8000$ RFU) were added.

\section{Stromal cell culture}

Following density gradient centrifugation the BMMC samples were incubated overnight at $37^{\circ} \mathrm{C}, 5 \% \mathrm{CO}_{2}$. After this time stromal cells had adhered to plastic, the nonadherent $\mathrm{T}$ cell enriched population was removed and was used for analysis or further culture. The adherent cells were further incubated in RPMI 1640 (Lonza) supplemented with 10\% FCS (Sigma-Aldrich) and 1\% Penicillin/Streptomycin (PAA) for one to two weeks and then removed from the plastic by trypsin/EDTA (Sigma). They were a heterogeneous population consisting of morphologically defined classical stromal cells, monocytes, dendritic cells and fibroblasts.

\section{CFSE staining}

To measure proliferation, $\mathrm{T}$ cells were stained with CFSE (Carboxyfluorescein succinimidyl ester). Briefly, cells were washed with PBS and stained with CFSE (Molecular Probes) for $10 \mathrm{~min}$ at $37^{\circ} \mathrm{C}$. T cells were washed twice with RPMI 1640 (Lonza) supplemented with 10\% FCS (SigmaAldrich) and 1\% Penicillin/Streptomycin (PAA). Proliferation was measured after 5 days using a FACSCanto II Instrument (BD Biosciences), and the data were analyzed using FACSDiva software (BD Biosciences).

\section{Statistical anaysis}

Differences between samples and groups were evaluated using paired or unpaired t tests, respectively. $p$ values $<0.05$ were considered as statistically significant.

\section{Abbreviation}

BM: Bone marrow; PB: Peripheral blood; BMMC: Bone marrow mononuclear cells; PBMC: Peripheral blood mononuclear cells; PMA: Phorbol 12-myristate 13-acetate; CMV: Cytomegalovirus; CDR3: Complementary determining region 3; RFU: Relative fluorescence unit; APC: Allophycocyanin;

MACS: Magnetic activated cell sorting. 


\section{Competing interests}

None of the authors has competing interests.

\section{Authors' contributions}

TP, BW and KLR performed experiments and analyzed the data. RR, JL, RG and MK provided bone marrow samples. DHB provided the iliac crest derived samples as well as some of his staining results. DHB and BGL designed the study protocol. TP, BW and BGL wrote the manuscript. All authors read and approved the final manuscript.

\section{Acknowledgement}

We thank Brigitte Jenewein, Michael Keller and Daniela Niederwieser for excellent technical assistance.

\section{Author details}

Institute for Biomedical Aging Research, University Innsbruck, Rennweg 10, Innsbruck, Austria. ${ }^{2}$ Department of Orthopedic Surgery, Innsbruck Medical University, Anichstrasse 35, Innsbruck, Austria. ${ }^{3}$ Department of CranioMaxillofacial and Oral Surgery, Innsbruck Medical University, Anichstrasse 35, Innsbruck, Austria. ${ }^{4}$ Present address: Yale University School of Medicine, 333 Cedar Street, New Haven, CT, USA.

Received: 21 December 2012 Accepted: 25 March 2013

Published: 4 May 2013

\section{References}

1. Di Rosa F, Pabst R: The bone marrow: a nest for migratory memory $T$ cells. Trends Immunol 2005, 26:360-366.

2. Tokoyoda K, Zehentmeier S, Chang HD, Radbruch A: Organization and maintenance of immunological memory by stroma niches. Eur J Immunol 2009, 39:2095-2099.

3. Herndler-Brandstetter D, Landgraf K, Jenewein B, Tzankov A, Brunauer R, Brunner S, Parson W, Kloss F, Gassner R, Lepperdinger G, GrubeckLoebenstein B: Human bone marrow hosts polyfunctional memory CD4+ and CD8+ T cells with close contact to IL-15-producing cells. J Immunol 2011, 186:6965-6971.

4. Herndler-Brandstetter D, Landgraf K, Tzankov A, Jenewein B, Brunauer R, Laschober GT, Parson W, Kloss F, Gassner R, Lepperdinger G, GrubeckLoebenstein B: The impact of aging on memory $T$ cell phenotype and function in the human bone marrow. J Leukoc Biol 2012, 91:197-205.

5. Abrahamsen JF, Lund-Johansen F, Laerum OD, Schem BC, Sletvold O, Smaaland R: Flow cytometric assessment of peripheral blood contamination and proliferative activity of human bone marrow cell populations. Cytometry 1995, 19:77-85.

6. Shen Y, Wang W, Li X, Liu Z, Markel DC, Ren W: Impacts of age and gender on bone marrow profiles of BMP7, BMPRs and Stro-1(+) cells in patients with total hip replacement. Int Orthop 2012, 36:879-886.

7. Fehrer C, Brunauer R, Laschober G, Unterluggauer H, Reitinger S, Kloss F, Gully C, Gassner R, Lepperdinger G: Reduced oxygen tension attenuates differentiation capacity of human mesenchymal stem cells and prolongs their lifespan. Aging Cell 2007, 6:745-757.

8. Landgraf K, Brunauer R, Lepperdinger G, Grubeck-Loebenstein B: The suppressive effect of mesenchymal stromal cells on $T$ cell proliferation is conserved in old age. Transpl Immunol 2011, 25:167-172

9. Schwanninger A, Weinberger B, Weiskopf D, Herndler-Brandstetter D, Reitinger S, Gassner C, Schennach H, Parson W, Wurzner R, GrubeckLoebenstein B: Age-related appearance of a CMV-specific high-avidity CD8+ T cell clonotype which does not occur in young adults. Immun Ageing 2008, 5:14.

10. Weinberger B, Welzl K, Herndler-Brandstetter D, Parson W, GrubeckLoebenstein B: CD28(-)CD8(+) T cells do not contain unique clonotypes and are therefore dispensable. Immunol Lett 2009, 127:27-32.

11. Brunner S, Herndler-Brandstetter D, Arnold CR, Wiegers GJ, Villunger A, Hackl M, Grillari J, Moreno-Villanueva M, Burkle A, Grubeck-Loebenstein B: Upregulation of miR-24 is associated with a decreased DNA damage response upon etoposide treatment in highly differentiated CD8(+) T cells sensitizing them to apoptotic cell death. Aging Cell 2012, 11:579-587.

12. Li G, Yu M, Lee WW, Tsang M, Krishnan E, Weyand CM, Goronzy JJ: Decline in miR-181a expression with age impairs T cell receptor sensitivity by increasing DUSP6 activity. Nat Med 2012, 18:1518-1524
13. Johnson PL, Yates AJ, Goronzy JJ, Antia R: Peripheral selection rather than thymic involution explains sudden contraction in naive CD4 T-cell diversity with age. Proc Natl Acad Sci U S A. in press.

14. Tokoyoda K, Zehentmeier S, Hegazy AN, Albrecht I, Grun JR, Lohning M, Radbruch A: Professional memory CD4+ T lymphocytes preferentially reside and rest in the bone marrow. Immunity 2009, 30:721-30.

15. Tokoyoda K, Hauser AE, Nakayama T, Radbruch A: Organization of immunological memory by bone marrow stroma. Nat Rev Immunol 2010, 10:193-200

16. Abumaree $M$, Al Jumah M, Pace RA, Kalionis B: Immunosuppressive properties of mesenchymal stem cells. Stem Cell Rev 2011, 8:375-92.

17. Tolar J, Villeneuve P, Keating A: Mesenchymal stromal cells for graft-versus-host disease. Hum Gene Ther 2011, 22:257-62.

18. Le Blanc K, Rasmusson I, Sundberg B, Gotherstrom C, Hassan M, Uzunel M, Ringden O: Treatment of severe acute graft-versus-host disease with third party haploidentical mesenchymal stem cells. Lancet 2004 363:1439-41.

19. Peggs K, Verfuerth S, Pizzey A, Ainsworth J, Moss P, Mackinnon S: Characterization of human cytomegalovirus peptide-specific CD8(+) T-cell repertoire diversity following in vitro restimulation by antigenpulsed dendritic cells. Blood 2002, 99:213-23.

20. Saurwein-Teissl M, Lung TL, Marx F, Gschosser C, Asch E, Blasko I, Parson W Bock G, Schonitzer D, Trannoy E, Grubeck-Loebenstein B: Lack of antibody production following immunization in old age: association with CD8(+) CD28(-) T cell clonal expansions and an imbalance in the production of Th1 and Th2 cytokines. J Immunol 2002, 168:5893-9.

21. Letsch A, Knoedler M, Na IK, Kern F, Asemissen AM, Keilholz U, Loesch M, Thiel E, Volk HD, Scheibenbogen C: CMV-specific central memory T cells reside in bone marrow. Eur J Immunol 2007, 37:3063-8.

22. Almanzar G, Schwaiger S, Jenewein B, Keller M, Herndler-Brandstetter D, Wurzner R, Schonitzer D, Grubeck-Loebenstein B: Long-term cytomegalovirus infection leads to significant changes in the composition of the CD8+ T-cell repertoire, which may be the basis for an imbalance in the cytokine production profile in elderly persons. J Virol 2005, 79:3675-83.

23. Pawelec G, Akbar A, Caruso C, Effros R, Grubeck-Loebenstein B, Wikby A: Is immunosenescence infectious? Trends Immunol 2004, 25:406-10.

24. Pawelec G, Akbar A, Beverley P, Caruso C, Derhovanessian E, Fulop T, Griffiths P, Grubeck-Loebenstein B, Hamprecht K, Jahn G, Kern F, Koch SD, Larbi A, Maier AB, Macallan D, Moss P, Samson S, Strindhall J, Trannoy E, Wills M: Immunosenescence and Cytomegalovirus: where do we stand after a decade? Immun Ageing 2010, 7:13.

25. Herndler-Brandstetter D, Schwaiger S, Veel E, Fehrer C, Cioca DP, Almanzar G, Keller M, Pfister G, Parson W, Wurzner R, Schonitzer D, Henson SM, Aspinall R, Lepperdinger G, Grubeck-Loebenstein B: CD25-expressing CD8+ T cells are potent memory cells in old age. J Immunol 2005, 175:1566-74.

doi:10.1186/1742-4933-10-17

Cite this article as: Pritz et al:: Bone marrow T cells from the femur are similar to iliac crest derived cells in old age and represent a useful too for studying the aged immune system. Immunity \& Ageing 2013 10:17.

\section{Submit your next manuscript to BioMed Central and take full advantage of:}

- Convenient online submission

- Thorough peer review

- No space constraints or color figure charges

- Immediate publication on acceptance

- Inclusion in PubMed, CAS, Scopus and Google Scholar

- Research which is freely available for redistribution 